\title{
STRUCTURAL ASSESSMENT OF THE 13TH CENTURY GREAT MOSQUE AND HOSPITAL OF DIVRIGI: A WORLD HERITAGE LISTED STRUCTURE
}

\author{
CEM DEMIR $* \dagger$, OMER FARUK HALICI ${ }^{\dagger \dagger}$, ALI NAKI SANVER ${ }^{\dagger \dagger \dagger}$, MUSTAFA COMERT ${ }^{\dagger \dagger \dagger}$, \\ FIKRET KURAN ${ }^{\dagger+\dagger}$, NICOLA BERLUCCHI ${ }^{\dagger+\dagger \dagger}$, ALI HURATA ${ }^{\dagger+\dagger}$ AND ALPER ILKI ${ }^{\dagger}$
}

${ }^{\dagger}$ Istanbul Technical University, Civil Engineering Faculty

Ayazaga Campus, 34750, Sariyer, Istanbul, Turkey

E-mail: demirce@itu.edu.tr*, ailki@itu.edu.tr - Web page: http://www.itu.edu.tr

${ }^{\dagger}$ MEF University, Department of Civil Engineering

Ayazaga Caddesi, No: 4, 34396, Sariyer, Istanbul, Turkey

E-mail: halicio@mef.edu.tr -Web page: http://www.mef.edu.tr

it RISE Engineering \& Consultancy

Eclipse Maslak C15, Maslak, Sariyer, Istanbul, Turkey

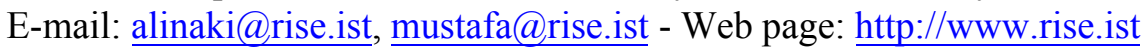

†i†' Directorate General of Foundations

Milli Müdafaa Caddesi, No: 20, Kızılay, Çankaya, Ankara, Turkey

E-mail: f.kuran@vgm.gov.tr, a.hurata@vgm.gov.tr -Web page: http://www.vgm.gov.tr

†t†' Studio Berlucchi S.r.1

Contrada Soncin Rotto, 4, Brescia, Italy

E-Mail: nicolaberlucchi@studioberlucchi.it -Web page: http://www. studioberlucchi.it

Keywords: Assessment, Masonry, Mosque, Seismic, Retrofit, World Heritage

Abstract. The Great Mosque and Hospital of Divrigi is located in the central eastern part of Turkey, in Divrigi, Sivas. The historical facility consists of a monumental mosque and a two-story hospital, which are adjacent to each other. The structure dates back to 13th century Mengujekids period and has been listed by the UNESCO as a World Heritage since 1985. Great Mosque and Hospital of Divrigi is particularly notable for its monumental stone portals that are decorated with three-dimensional ornaments carved from stone. The structural system of the monument consists of multi-leaf stone masonry walls and stone piers that support the roof structure which consists of stone and brick arches and vaults. The structure is located about $90 \mathrm{~km}$ away from the North Anatolian Fault Line, that has been causing several destructive earthquakes. Consequently, the structure is prone to destructive seismic activities. In this study, after a brief introduction on the structural system and current condition of the structure, the structural performance of the Great Mosque and Hospital of Divrigi is investigated through site observations and structural analyses. For this purpose, linear and nonlinear $3 D$ finite element models of the structure are developed and the structure is examined under the effects of vertical loads and seismic actions. In the light of the analyses results, recommendations for potential interventions are outlined for further preservation of the structure. 


\section{INTRODUCTION}

The Great Mosque and Hospital of Divrigi (Figure 1), an UNESCO World Heritage listed structure since the year 1985 , dates back to the Mengujekids period (13 ${ }^{\text {th }}$ century). The structure, located in the central eastern part of Turkey (today Divrigi, Sivas), is constructed on a sloped hill. Great Mosque and Hospital of Divrigi is particularly notable for its monumental stone portals and vaults that are decorated with three-dimensional ornaments carved from stone (Figures 2 and 3). The structure is a unique piece of civil architecture of its period and several restoration works had been performed in the past. However, the monument still needs further attempts for enhancement of the structural system, repair of damages, removal of the traces of past malpractice and conservation of its exceptional architectural features. For this purpose, Ministry of Culture and Tourism and General Directorate of Foundations of Turkey have recently launched an extensive restoration campaign, which is being carried out by a group of experts from various disciplines. The structural analyses presented in this study is a short summary of several efforts spent in the scope of this project.

In this study, after a brief introduction of the structural system and current condition of the monument, the structural performance of the Great Mosque and Hospital of Divrigi is investigated through site observations, historical records and structural analyses. For this purpose, a 3D finite element model of the structure is developed and examined under the effects of vertical loads and seismic actions. For realization of the linear and nonlinear structural analyses, the recommendations given in the Guidelines for Management of Seismic Risks for Historical Constructions document are followed [1]. In the light of the analys es results, the potential reasons for existing damages and previous interventions are investigated recommendations for potential interyentions structure. It should be noted thr approved and applied. S

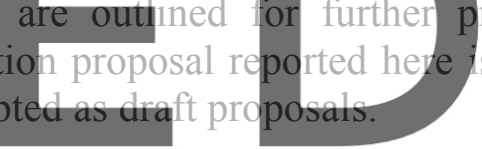
not $y e$

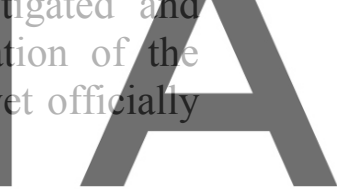

Register for free at https//www.scipedia.com to download the version without the watermark
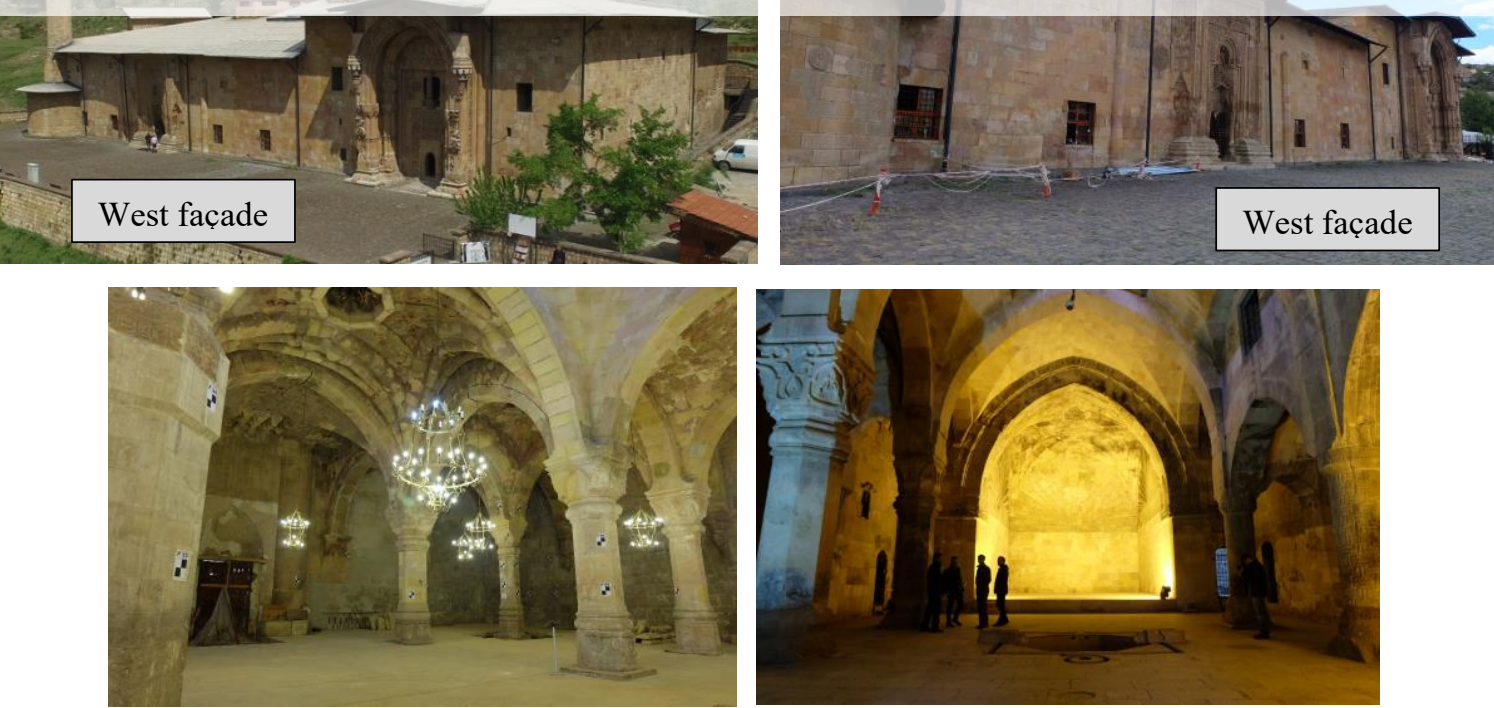

Figure 1: Exterior and interior views of the structure 

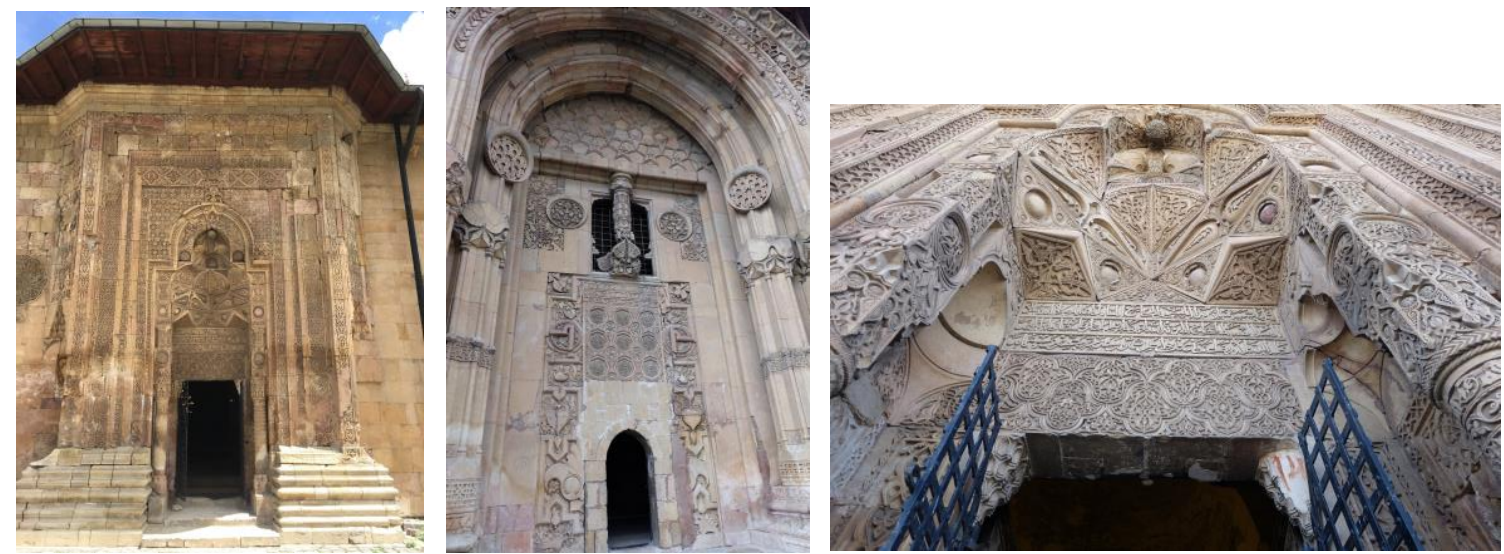

Figure 2: Decorated monumental stone portals

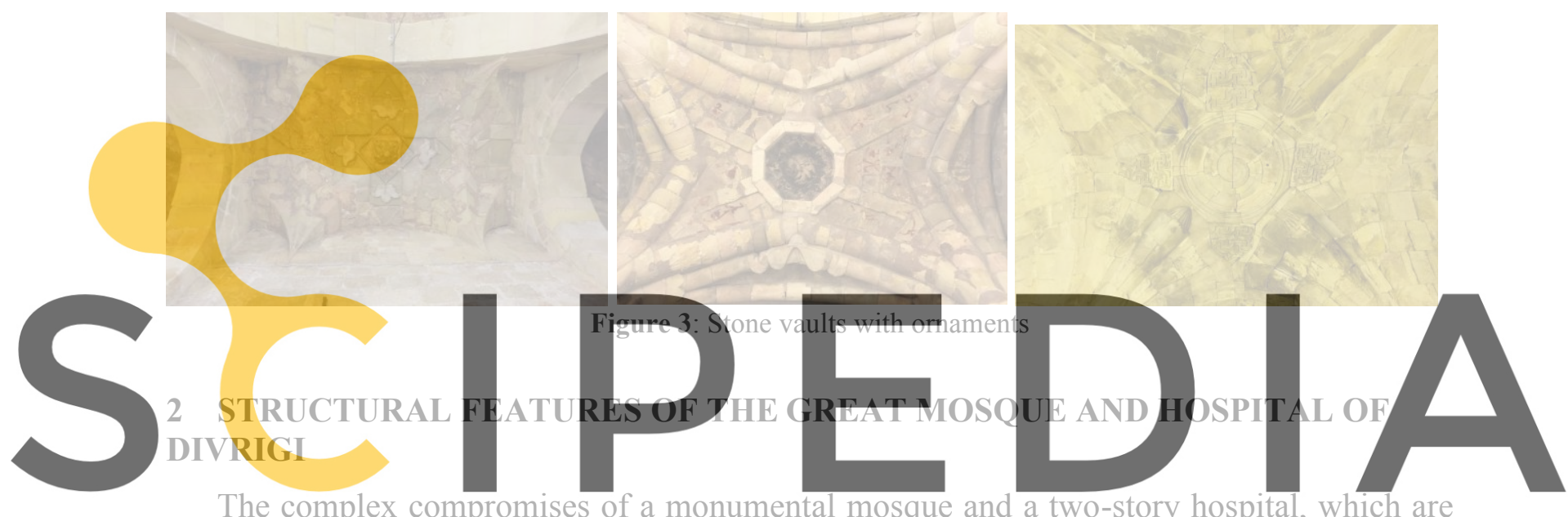

The complex compromises of a monumental mosque and a two-story hospital, which are

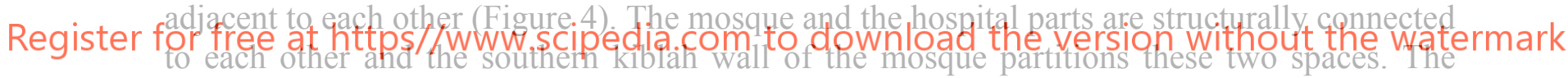

structural system of the Great Mosque and Hospital of Divrigi consists of stone masonry walls and stone piers that support the vaulted roof structure. The dimensions of the structure are approximately $73 \mathrm{~m} \times 32 \mathrm{~m}$ in plan and the average height for façades is about $12 \mathrm{~m}$. The façade views can be seen in Figure 2.

The walls are approximately $1.4 \mathrm{~m}$ thick multi-leaf walls with cut-stone outer leaves and a rubble masonry infill. The roof structure consists of stone arches and vaults. The only exception to this use of stone masonry is the brick masonry vaults (Figure 5) covering the areas adjacent to the western façade that are known to be damaged/collapsed and rebuilt together with stone buttresses adjoining with the western façade main wall. Another surviving trace of this incident is the significant out-of-plumb top displacement (almost $60 \mathrm{~cm}$ ) of the mosque section western façade wall and portal (Figure 6).

Located at about $90 \mathrm{~km}$ away from the North Anatolian Fault Line, that is known to have created $\mathrm{M}_{\mathrm{w}}>7.0$ earthquakes in the past, the structure is prone to destructive seismic activities. Being in such an active seismic region, the structure underwent several extensive repair and intervention works not only during the Ottoman, but also during the Republic periods. Although at its current state the structure is intact, several structural deformations in the form of cracks, 
material losses and dislocations can be observed over the walls, piers and vaults (Figure 7). Additionally, material deteriorations and traces of malpractices of past restoration works (i.e.. poor workmanship, use of unsuitable materials like cement, interventions structurally and architecturally not coherent with the original techniques) can also be widely observed.

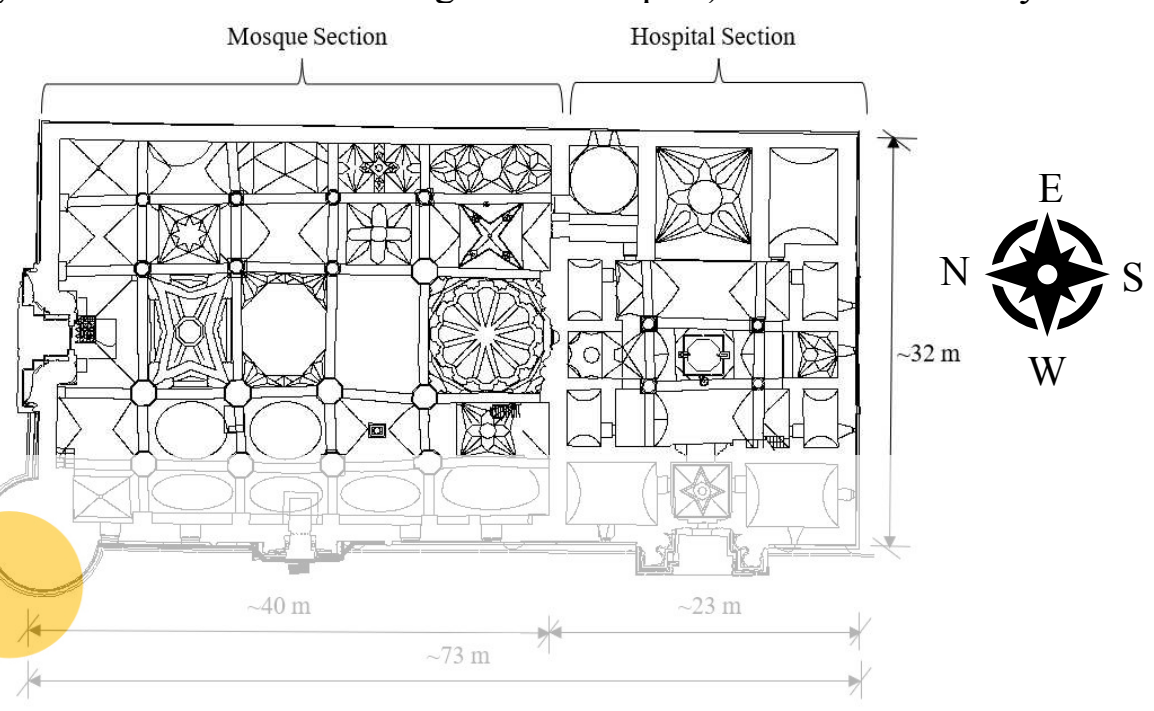

Figure 4: Plan view of the structure
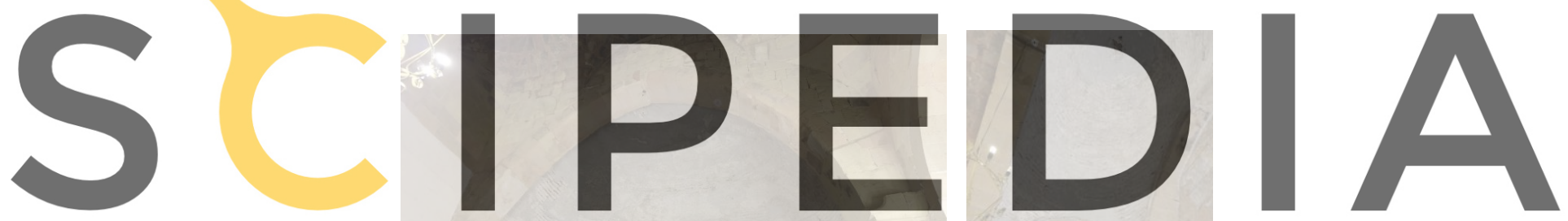

Register for free at https//www.scipedia.com to download the version without the watermark

Figure 5: Brick vaults adjacent to the western façade of the mosque section
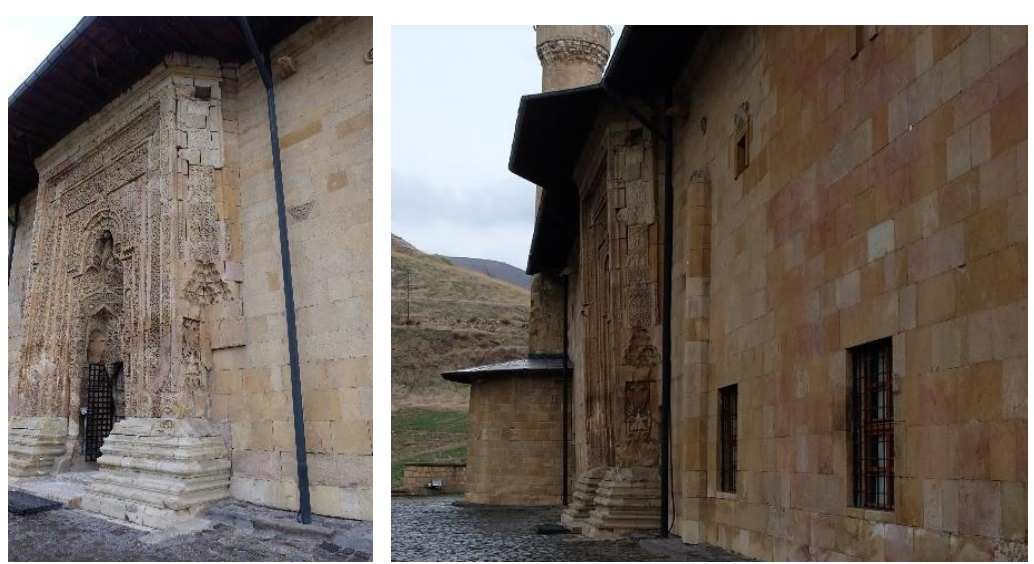

Figure 6: Out-of-plumb deformation of the western façade mosque portal 

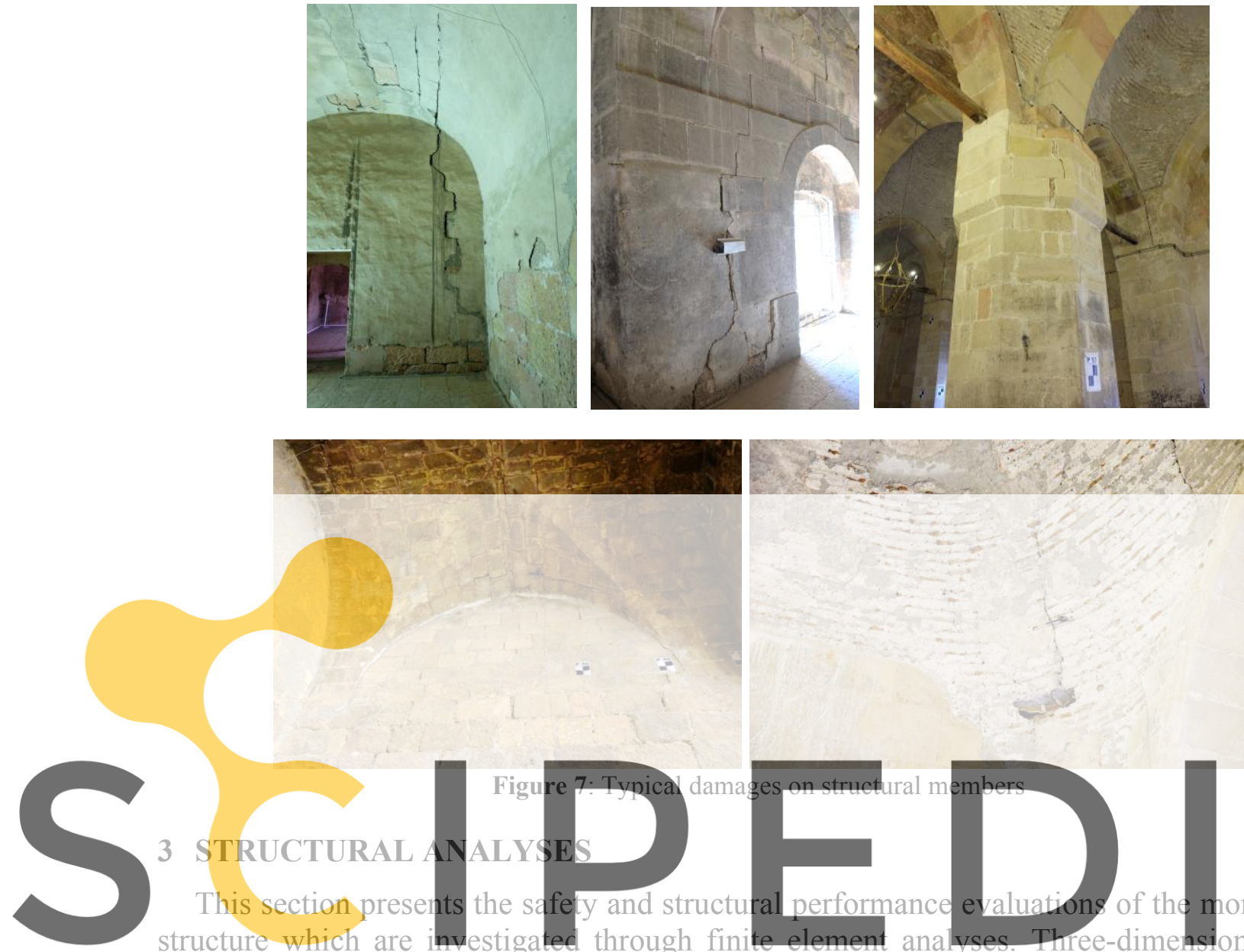

3 STRUCTURAIL

This section presents

structure which are
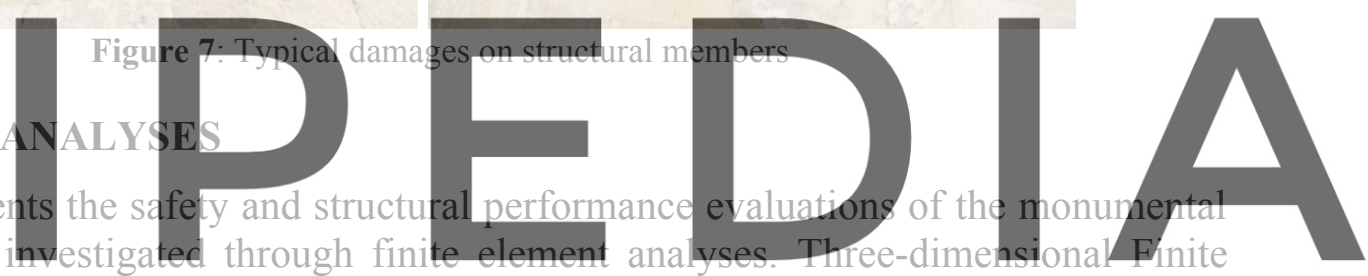

Element (FE) models representing the present condition and deficiencies of the structure were

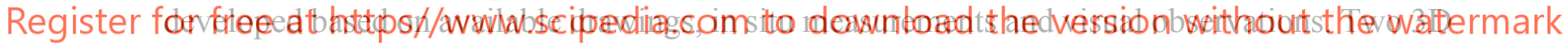

FE models were created to evaluate the behavior of the structure under vertical loads and

representative seismic actions. The first FE model was formed with linear elastic approach to assess the global response, stress distributions, and safety of the structure. While the second FE model was constructed to specifically investigate the safety status of the western façade wall, which has tilted nearly $4^{\circ}$ thought to have occurred during past earthquakes. A nonlinear approach in terms of material and geometry was adopted in the second FE model.

The general modeling assumptions and the brief results obtained from these two FE models are presented in the following subsections.

\subsection{Linear Elastic Analysis Investigating the Global Response of the Structure}

The first model was established using SAP2000 v20 structural analysis program [2]. Structural components such as walls, vaults, and domes were modeled with 2D four-node shell elements with three translational degree of freedoms at each node. While components including stone piers and arches were modeled with two-node beam elements. General views of the structural model are presented in Figure 8. Structural safety was evaluated based on the implications stated in Guidelines for Management of Seismic Risks for Historical Constructions 
[1], where the components of the structures having world-wide importance are proposed to have sufficient capacity against the effects of vertical loads and earthquake actions with 2475-year return period considering a seismic load reduction factor $(\mathrm{R})$ of 3 (indicated as Controlled Damage performance level in [1]). For this purpose, site-specific earthquake spectra were developed for the earthquakes with return periods of 72, 475 and 2475 years. Among these ground motions 72 years was used for design of the temporary shoring structures to be used during the restoration works and 475 years to check the western façade wall out-of-plane performance. In the determination of such spectra, the attenuation relationship developed by Campbell and Bozorgnia [3] was benefited considering the seismic faults near the area.

The mechanical properties of the structural materials were taken from [1] based on the site observations and masonry quality. Accordingly, the modulus of elasticity values for the stone masonry and brick masonry were taken as $1750 \mathrm{MPa}$ and $2100 \mathrm{MPa}$, respectively. Similarly, the compressive and tensile strengths of stone masonry were considered as $1.80 \mathrm{MPa}$ and 0.20 $\mathrm{MPa}$, respectively. While they were $2.20 \mathrm{MPa}$ and $0.20 \mathrm{MPa}$ and for brick masonry, respectively. Also, the initial shear strength values were $0.065 \mathrm{MPa}$ and $0.075 \mathrm{MPa}$ for stone and brick masonry. The results of the structural analyses indicated that under gravitational loads and 2475-year return period seismic action, the obtained compressive stress values did not exceed the compressive strength values defined for the brick and stone masonry. However, the tensile stress values obtained at the critical sections of the vaults and the domes were generally greater than the assumed tensile strength values. Figure 9 shows the tensile stress distribution

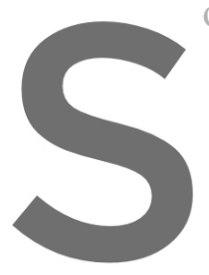
obtained for the roof structure
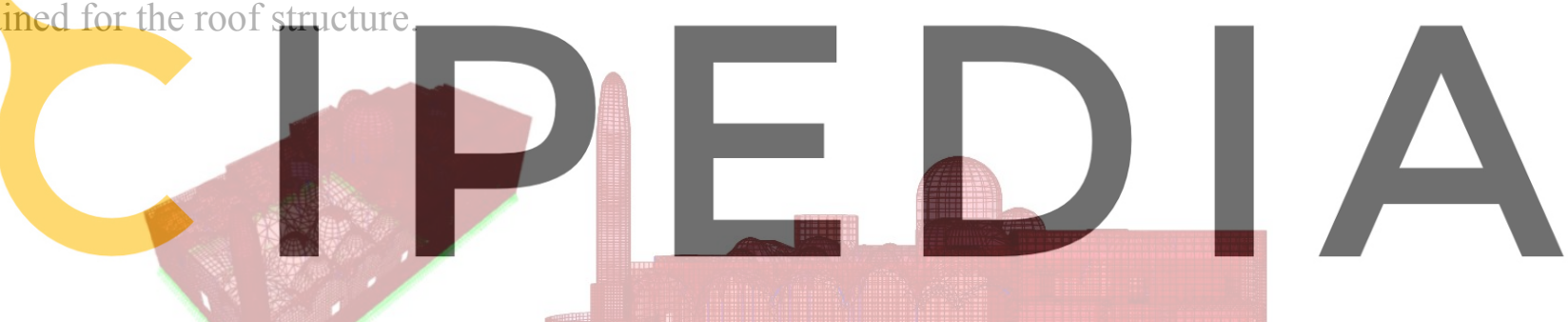

Register for free at https//www.scipedia.com to download the version without the watermark

Figure 8: General views of the first FE model

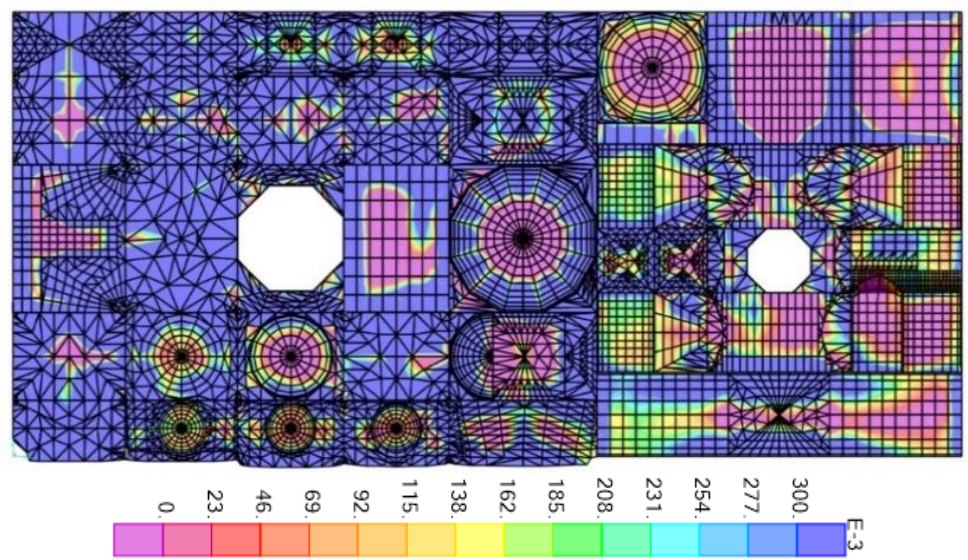

Figure 9: Tensile stress distribution for the roof structure [MPa] 
The shear stress values obtained for the masonry walls were compared with the calculated shear strengths of the materials. The shear strength $(\tau)$ at the critical sections was calculated using Equation 1, where $\tau_{0}$ is the initial shear strength and $\sigma$ is the compressive stress at the corresponding section. Shear stress distribution obtained for the western wall is shown in Figure 10.

$$
\tau=\tau_{0}+0.4 \sigma
$$

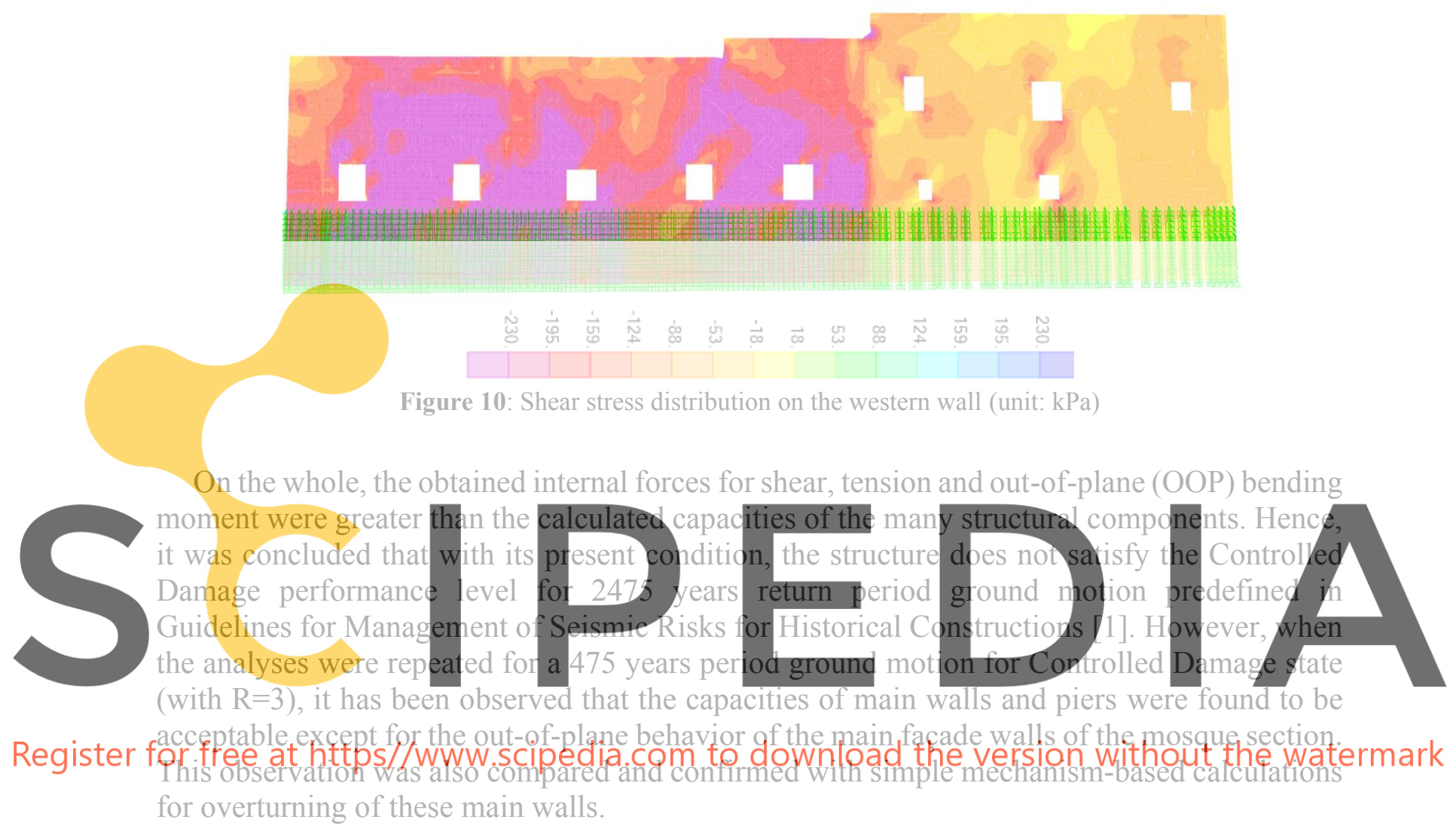

\subsection{Nonlinear Analysis Investigating the Response of the Western Wall}

The second FE model was developed by using Abaqus 2019 FE software [4]. As the main purpose of this FE model was to investigate the safety of the tilted part of the western façade wall, the wall and the supporting buttresses (which were added to the inner face of the western façade wall during past interventions) were modeled in detail using eight-node 3D solid elements with simplified micro modeling approach. Material and geometric nonlinearity approaches were adopted in the modeling of the western wall. All other structural components were modeled as in the first FE model described in Section 3.1. Besides the tilted part of the western wall, other components of the structure were included in the model in order to represent the wall boundary conditions realistically. General views of the model are shown in Figure 11. Due to different modeling approaches and the tilted geometry of the western wall, gaps between the western wall and the adjacent walls were present in the model. Nonetheless, kinematic constraints were defined in those regions to provide connection between structural elements. 
The multi-leaf masonry wall is made of two cut stone masonry units at the exterior and interior faces which are separated by rubble stone masonry units in the middle. Further information on the behavior multi-leaf walls can be found in [5-7]. The dimensions of the examined part of the western wall are 33 meters in length, 12 meters in height. The thickness of the wall is 1.4 meter. The rubble stone masonry was modeled as one solid part, while the cut stone masonry units were modeled as separated micro elements. In order to represent the randomness of the stone unit configuration, different cut stone unit dimensions were assembled in the model. The length of the cut stone units was ranging between 0.40 and 0.80 meter, whereas the thickness of the units was either 0.30 or 0.45 meter. The assembled wall configuration is presented in Figure 12.

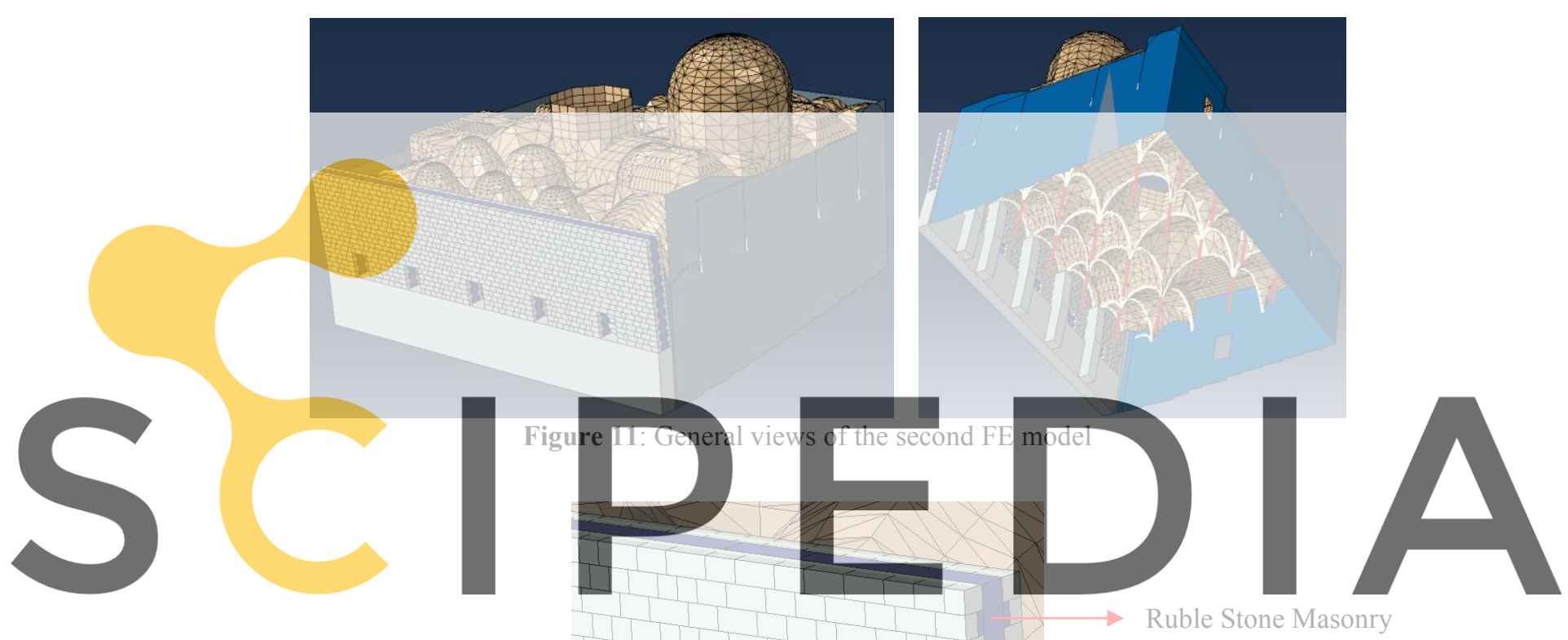

Register for free at https//www.scipedia.com to download the version without the watermark

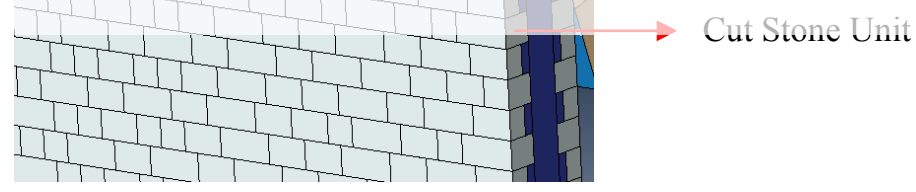

Figure 12: Wall configuration with different wall unit geometries

The nonlinear stress-strain relationship for the rubble masonry wall is presented in Figure 13a. The cut stone masonry units were modeled with linear elastic material properties with a Young's Modulus of $2500 \mathrm{MPa}$. The interface behavior between rubble stone and cut stone units were modeled with nonlinear cohesive-frictional interaction properties. Hard contact was defined between all surfaces in contact. The cohesive-frictional interfaces remain elastic until the normal stress and/or shear stress values at the interfaces reach the specified strength values ( $f_{t i}$ for interface tensile strength, $\tau_{\text {oi }}$ for interface initial shear strength in Table 1 ). Then, the interactions continue to transfer shear forces with respect to the friction coefficient $(\mu)$ and the normal stress $(\sigma)$ acting on the surface. Conversely, the interfaces between cut stones were modeled without cohesion and tensile strength as no grout between 
stone units was observed during site visits. The selected interaction properties at different interfaces are outlined in Table 1 .

Table 1: Interaction properties at the interfaces

\begin{tabular}{cccc}
\hline Interface & $\mathrm{f}_{\mathrm{ti}}[\mathrm{MPa}]$ & $\tau_{\mathrm{oi}}[\mathrm{MPa}]$ & $\mu$ \\
\hline Rubble Stone - Cut Stone & 0.10 & 0.20 & 0.50 \\
\hline Buttress - Cut Stone & 0.10 & 0.20 & 0.50 \\
\hline Cut Stone - Cut Stone & - & - & 0.50 \\
\hline
\end{tabular}
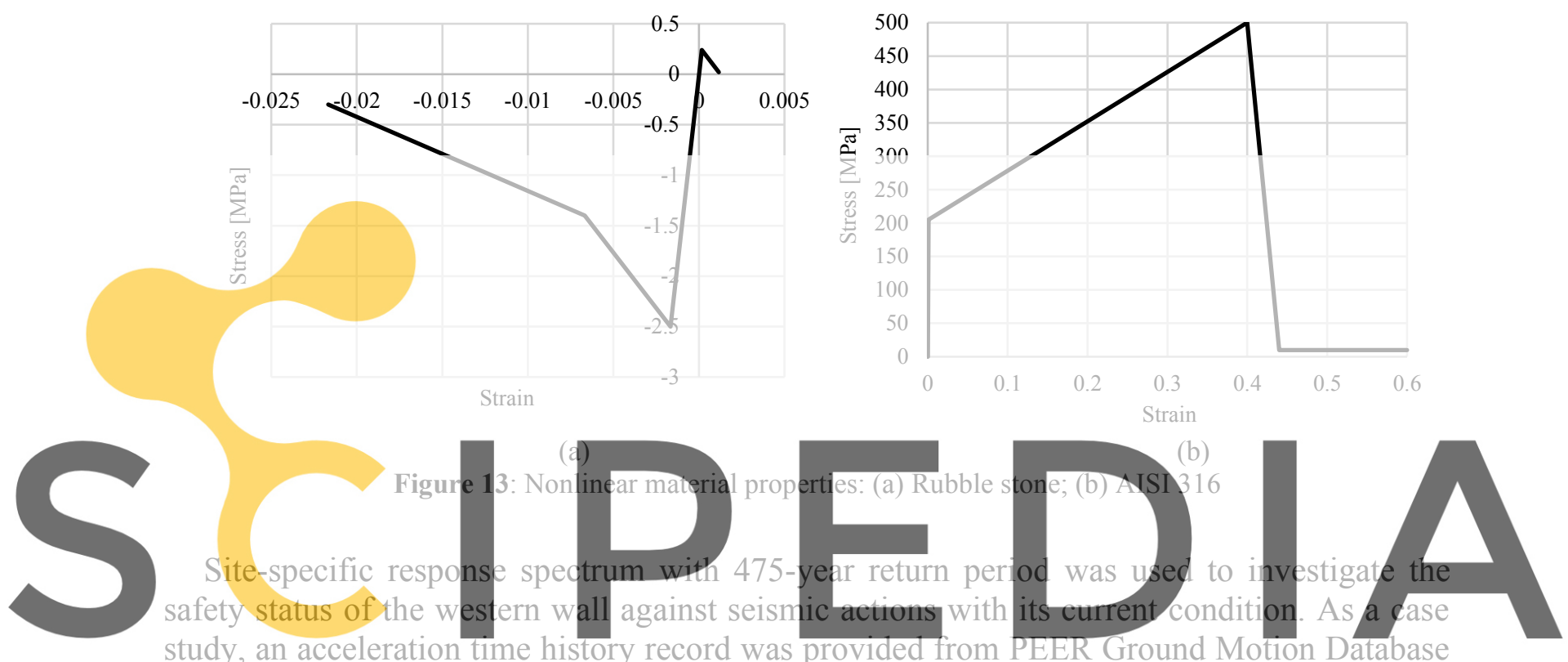

study, an acceleration time history record was provided from PEER Ground Motion Database Registe [8]. H1 component of 'RSN11.61' Kocaeli earthquake record (1999) was selected and scaled by

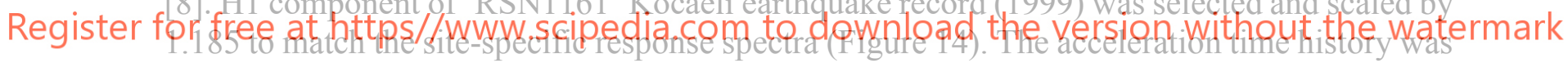
applied in the out-of-plane (OOP) direction of the western wall. In the time-history analysis, the wall exhibited large OOP displacements which eventualily initiated the instability and resulted with the collapse of the wall (Figure 15).
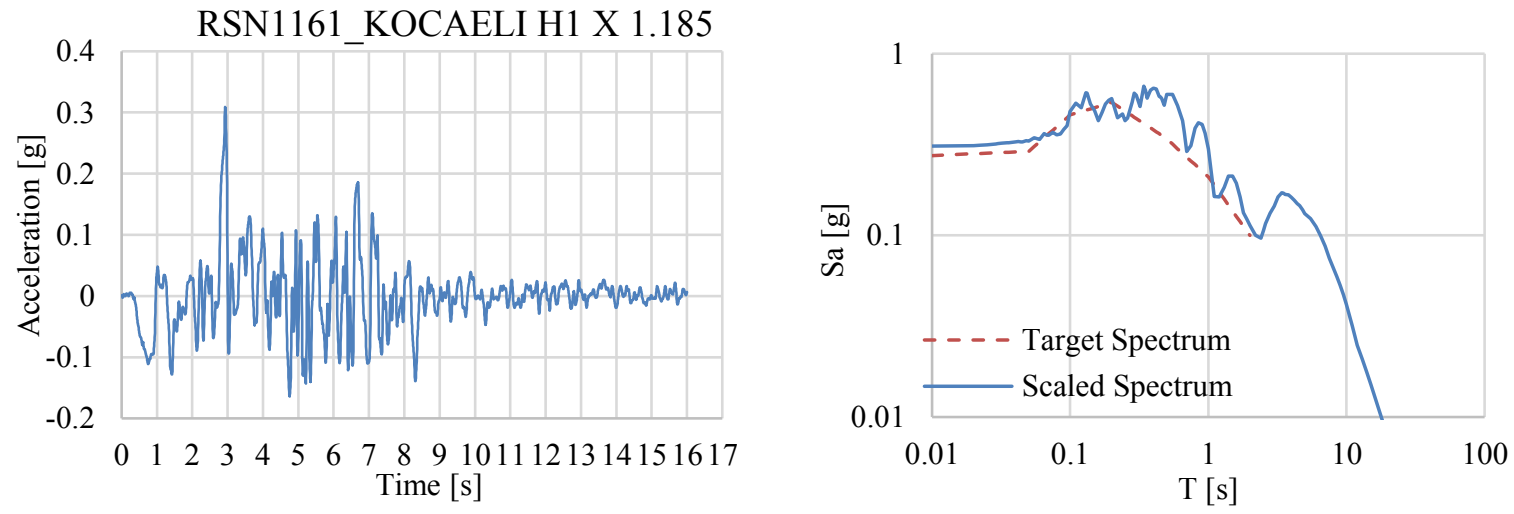

Figure 14: (a) Selected acceleration record, (b) target and obtained response spectra 


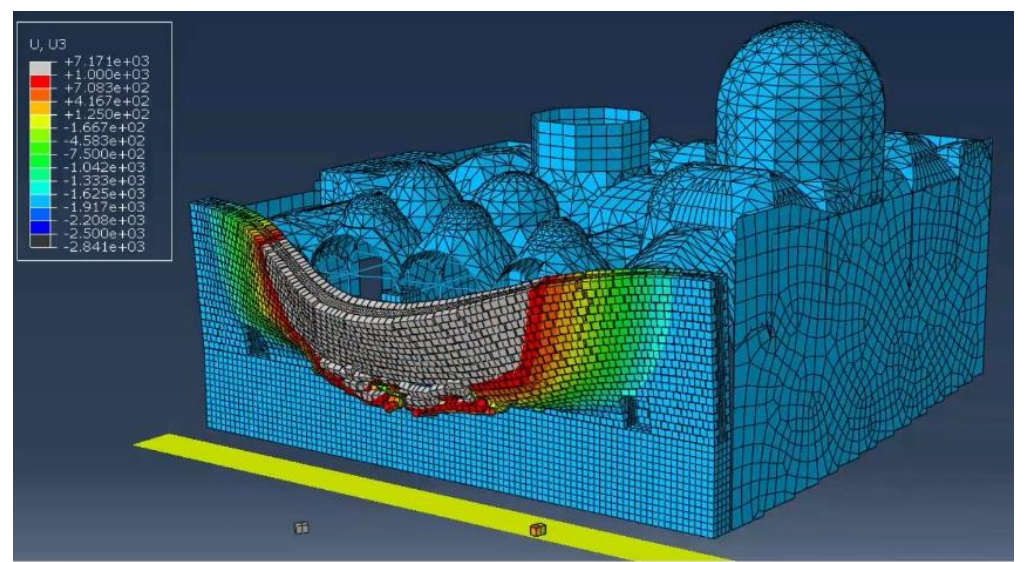

Figure 15: Out-of-plane collapse of the western façade wall observed during the time-history analysis (horizontal displacement contour in mm unit)

\section{REHABILITATION METHODOLOGY PROPOSAL}

Linear and nonlinear structural performance analyses showed insufficient capacity of the structure against the combination of gravitational and seismic load effects. The internal forces within the walls, such as shear, tension and moment exceeded the relevant capacities of the load bearing members. Based on these analyses results and site observations, a series of structural interventions was proposed to enhance the behavior of the structure against future earthquakes.

In order to enhance the structural integrity and increase the OOP bending monent capacity, steel-timber composite bonding beams were proposed to be placed above the main walls. " projected system includes two timber beams having 100 x $100 \mathrm{~mm}$ x mm cross-section dimensions with two steel plates attached on both sides of each timber frame. The attached/steel plates have $10 \times 100 \mathrm{~nm} \times \mathrm{x}$ m cross-section dimensions. In plan, the two composite beams are connected together by steel cross ties at each $750 \mathrm{~mm}$ distance. The cross ties have square tube

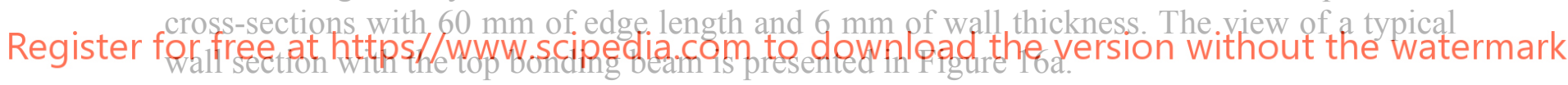

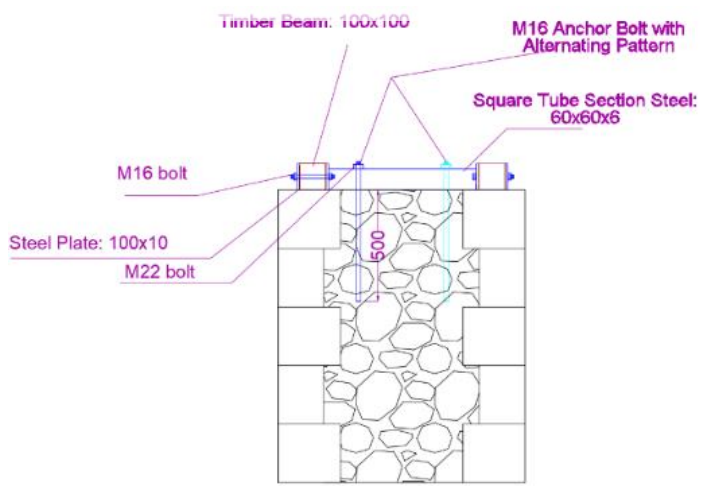

(a)

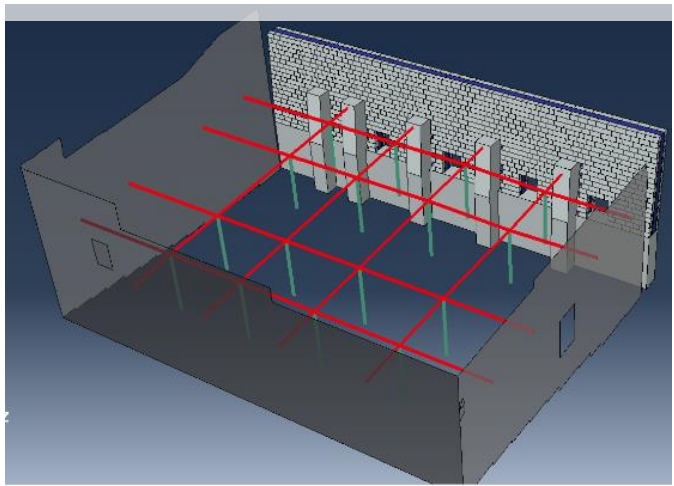

(b)

Figure 16: (a) Cross-section of wall with composite bonding beam (units mm), (b) layout of ties between piers and walls

The second recommended rehabilitation methodology to improve the structural performance was bracing the piers and the walls with stainless steel ties. It should be noted that, in the current state, only the naives close to the western façade are reinforced with timber ties. In order to 
provide ties to whole structure, 50-mm-diameter tension rods with AISI 316 steel class were proposed to connect the vertical components of the structure. The stress-strain relationship of AISI 316 and a view of the planned layout of the steel ties are shown in Figure 13b and Figure $16 \mathrm{~b}$, respectively.

The described rehabilitation methodologies above were then defined in the nonlinear FE model and the time-history analysis was repeated under the same earthquake excitation. The rehabilitated wall did not exhibit instability and managed to withstand the seismic excitations until the end of the analysis. Displacement time histories measured at the top of the wall are presented in Figure 17 for both cases. It was concluded that, with the application of the proposed rehabilitation methods, the OOP displacement of the western wall can be reduced to nearly $25 \%$ of the same displacement obtained with the present condition of the wall.

In addition to the above mentioned reinforcing methodologies, other structural interventions such as lime grout injection to walls and cracks, local repairs, replacement of heavily damaged/decayed masonry units, retrofitting of vaults with textile reinforced mortar (TRM) and bracing of cracked piers/pier caps are also planned.

In order to protect the structure from harsh weather conditions of the region during the extensive restoration works; a temporary roof structure has been designed and constructed as can be seen in Figure 18. The light roof system formed with steel and aluminum members has a single span in the transverse direction (approximately $40 \mathrm{~m}$ long) and has the ability to melt the snow during the winter season by the help of a heater system.

It should be also noted that an extensive structural health monitoring (SHM) system with more than 70 channels has been activated for continuously observing the structure electronically before, during and after the restoration works which is still under operation.

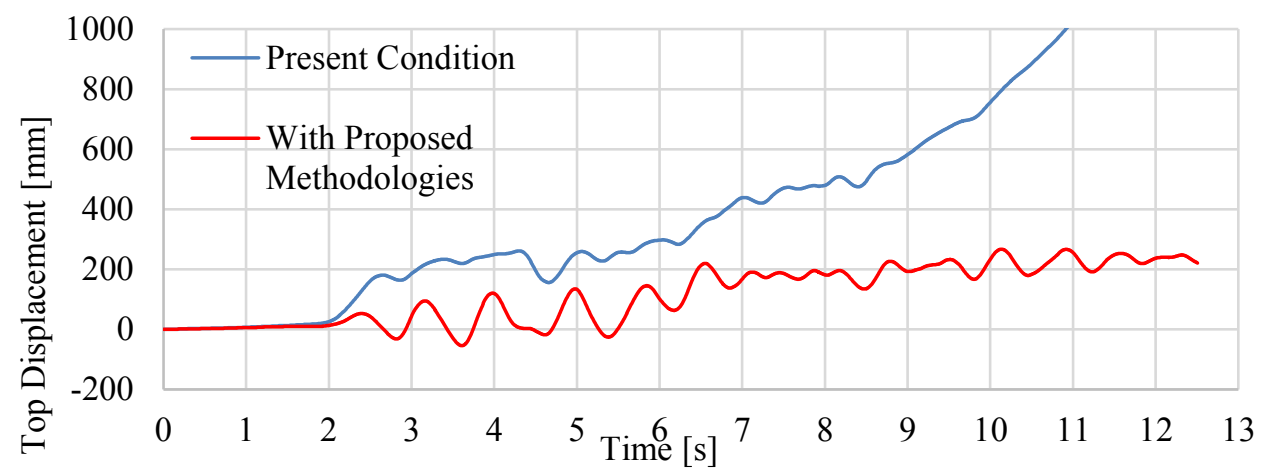

Figure 17: Wall out-of-plane displacement at the top (measured relative to the ground)

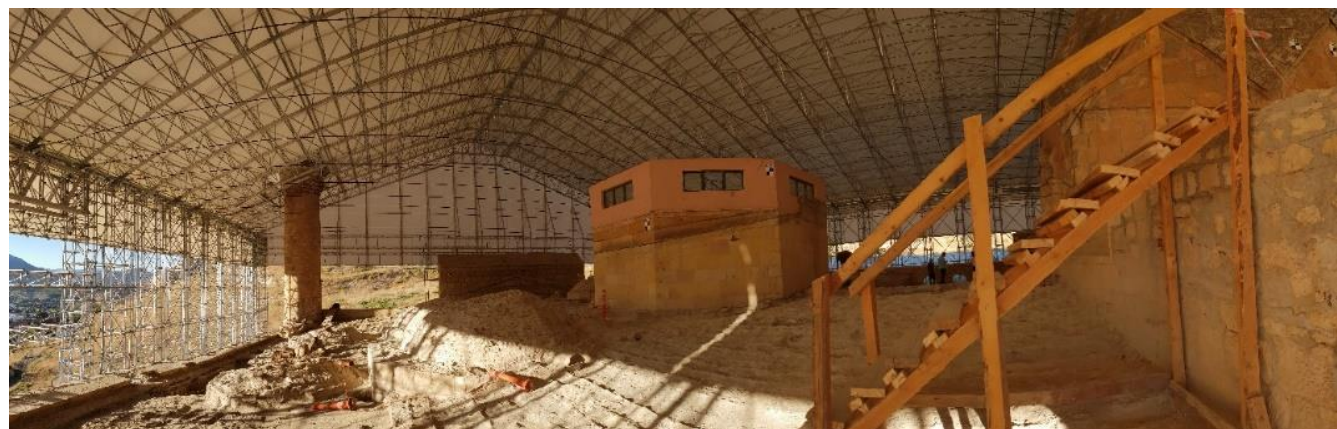

Figure 18: Temporary roof structure for protecting the structure during the restoration works 


\section{CONCLUSIONS}

In this study, the seismic performance of the Great Mosque and Hospital of Divrigi located in eastern Turkey was investigated through site observations and structural analyses. The linear and nonlinear finite element models of the $13^{\text {th }}$ century UNESCO World Heritage structure was constructed, and the seismic performance of the monument was assessed for the combined actions of vertical and seismic loads. The analyses results indicated that the structural performance of the Great Mosque and Hospital of Divrigi may have some flaws particularly for the out-of-plane behavior of $12 \mathrm{~m}$ high western wall. Consequently, a rehabilitation scheme including the introduction of stainless steel ties and wall-top bonding beams has been proposed for enhancing the seismic performance of the structure. The nonlinear finite element analyses results show that with the proposed interventions, the integrity of the structural system can be significantly enhanced, and the seismic capacity can be considerably improved.

Acknowledgements. The authors would like to express their sincere gratitude to Directorate General of Foundations and Ministry of Culture and Tourism of Turkey for their generous supports during the study. Contractors of the restoration project, Kadioglu Construction and Dor Yapi Construction companies are also acknowledged.

\section{REFERENCES}

[1] Guidelines for Management of Seismic Risks for Historical Constructions, Directorate General of Foundations, Ankara, Turkey (Online in Turkish: https://www.ipkb.gov.tr/tr/yayinlar), (2017).

[2] Computers and Structures. SAP2000 v20 Integrated finite element analysis and design of structures basic analysis reference manual. Computers and Structures, Inc., Berkeley, California, USA, (2018).

[3] Campbell, K.W. and Bozorgnia, Y. NGA Ground Motion Model for the Geometric Mean Horizontal Component of PGA, PGV, PGD and 5\% Damped Linear Elastic Response Spectra for Periods Ranging from 0.01 to 10 s. Earthquake Spectra, 24(1), 139-171, (2008).

[4] Abaqus F.E.A. “Analysis User's Manual” Dassault Systemes Simulia Corp., Providence, RI, (2019).

[5] Demir, C. and Ilki, A. Characterization of the materials used in the multi-leaf masonry walls of monumental structures in Istanbul, Turkey. Construction and Building Materials, 64, 398-413, (2014).

[6] Demir, C., Dogu, E., Ispir, M. and Ilki, A. Seismic Behavior of Ottoman Empire Classical Period Stone Masonry Walls. In: 10th International Conference on Urban Earthquake Engineering (10CUEE), Tokyo Institute of Technology, (2019).

[7] AlGohi, B.H., Baluch, M.H., Rahman, M.K., Al-Gadhib, A.H. and Demir, C. PlasticDamage Modeling of Unreinforced Masonry Walls (URM) Subject to Lateral Loading. Arabian Journal for Science and Engineering (2017) 42(9), 4201-4220.

[8] Chiou, B., Darragh, R., Gregor, N. and Silva, W. NGA Project Strong-Motion Database. Earthquake Spectra (2008) 24(1), 23-44. 